УДК 347.73

DOI https://doi.org/10.32849/2663-5313/2019.5.35

\title{
Вima Форскок,
}

здобувач кафедри фінансового права

юридичного факультету

Київського начіонального університету імені Тараса Шевченка

\section{ФІЛОСОФСЬКО-ПРАВОВІ АСПЕКТИ ТЛУМАЧЕННЯ ПРИНЦИПІВ ПОДАТКОВОГО ПРАВА}

У статті розглядається питання тлумачення приниипів оподаткування для правозастосовноі практики. Зокрема, автором наголошується, що тлумачення конкретної норми принципу повинно здійснюватися не відособлено, а в контексті всвого нормативно-правового акту, тобто Податкового кодексу України. Крім того, інтерпретачія не є усталеною та вичерпною, а зумовлена об'єктивними знаннями про світ, суб'єктивним горизонтом інтерпретатора та інтерсуб'єктивною включеністю в певну мовно-комунікативну спільноту. Автор зазначає, що помилковою є практика, коли інтерпретатор намагається дослідити первісний зміст закону замість усвідомлення змін, які відбулися з моменту прийняття закону, мети і завдань правового регулювання, а тому в кожному конкретному випадку слід визначати нормативну функиію закону, іншими словами - потрібно зрозуміти сутність закону з урахуванням конкретних об'єктивних обставин.

Ключові слова: тлумачення закону, принципи податкового права, юридична герменевтика, горизонт пізнання інтерпретатора.

Постановка проблеми. За своєю суттю принципи оподаткування - це завжди певні ідеї, концепти, абстракції, які спочатку викристалізовуються в межах певних наукових доктрин, а в подальшому тією чи іншою мірою можуть бути рецепійовані іншими агентами в межах їх інтерпретацій [1]. У контексті правових ідей такими реципієнтами може виступати держава, надаючи їм зовнішнього вираження в проявах державної політики або в межах нормативних актів, або судді, формуючи судові доктрини, i, безумовно, залежно від особи - інтерпретатора, його цілей, соціокультурного та морального середовища, яким він себе обмежує, чи глибини їх сприйняття, вказані ідеї зазнають значної трансформації.

Останні дослідження і публікації. У процесі написання статті було вивчено безліч наукових праць вітчизняних i зарубіжних дослідників, у тому числі С.С. Алексєєва, Р.О. Гаврилюк, Г. - Г. Гадамера, В.Н. Карташова, Р.З. Лівшиця, С.П. Рабиновича та інших.

Метою цієї статті є дослідження філософсько-правових аспектів тлумачення принципів податкового права, чинників, які впливають на сприйняття принципів податкового права інтерпретатором, а також ролі горизонту свідомості самого інтерпретатора.
Виклад основного матеріалу. На думку С.С. Алексєєва, правові ідеї зароджуються на юридично-інтелектуальному пласті правової матерії [2], а в подальшому можуть бути сприйняті законодавцем у межах нормативних текстів [3].

У цьому контексті російський правознавець В.Н. Карташов виділяе три групи принципів: позитивного права, доктринальні i практично-прикладні [4]. На наш погляд, зазначена класифікація відображає три найважливіших сфери буття права: норми права, юридичну науку та втілення правових приписів у суспільній практиці. Великий пізнавальний потенціал має обгрунтований цим вченим висновок про множинність структур у рамках однієї і тієї ж системи принципів права (включаючи кожен 3 них): «Уся система принципів i кожен із них окремо є поліструктурними утвореннями, що включають, зокрема, логічну і стохастичну, генетичну і функціональну, тимчасову і просторову, горизонтальну і вертикальну, синергетичну і рекурсивну, циклічну і інші види структур» [5].

Офіційна легалізація принципів податкового права може бути різною: частина 3 них може бути формалізована як спеціалізовані норми, інші - лише побіжно згаданими в джерелах податкового права, треті - індуктивно виведеними з контексту цілого ряду правових норм і інститутів. Така легалізація може здійснюватися як законодавцем - у процесі 
видання нормативних правових актів, так і судами - в рамках реалізації їх дискреційних повноважень, або іншими учасниками податкових відносин - шляхом формування стійкої правозастосовної практики та її санкціонування державою.

Прикладний потенціал принципів реалізується: під час тлумачення податково-правових норм; під час оцінки їх конституційності; для посилення юридичної аргументації у справі; у випадку обмеження дискреційної волі суб'єктів; під час відмежування кваліфікованого мовчання закону від прогалин у праві; під час вирішення податкових спорів підвищеної складності (невиправна прогалина, колізія норм однакової юридичної сили i т. п.) [6].

I, як наслідок, ці ідеї знаходяться в постійному розвитку свого розуміння і пізнання, залежать від світогляду і контексту, в якому існує їх реципієнт. У цьому контексті нам дуже правильним представляється зауваження Г.А. Гаджиєва про особливості формування правової реальності конституційних принципів, адже дійсно, беручи до уваги особливості історичної долі народу, можна стверджувати, що конституція кожної держави кодифікує найважливіші юридичні норми і одночасно «кодифіковані» соціокультурні традиції, які склалися, mores - i в цьому сенсі ті правила, які відображають зв’язок із минулим народу [7].

Зазначене зауваження повною мірою може бути екстрапольоване і щодо Податкового кодексу України та принципів оподаткування, які закріплені в статті 4 цього закону.

3 огляду на те, що розуміння виникає на тлі попередніх афектацій, воно завжди грунтується на нашій історії [8]. На історичності досвіду під час спроби експлікації фундаментальних екзістенціалів Dasein відзначав Мартін Гайдегер. Саме завдяки історичності як властивій рисі онтологічного буття людина не займає сторонньої позиції історіографа, а здатна бути включеною в ситуацію, яка розгортається на базі її упереджень, наявного досвіду і майбутніх звершень, а відтак може екзистувати до свого буття і інтерполювати даність у горизонт свого розуміння.

Ганс-Георг Гадамер, у свою чергу, модальність буття герменевтичної свідомості визначає через дієво-історичну природу. Звідси слідує, що розуміння є історично навантаженим, а інтерпретація завжди виходить із конкретного горизонту, зумовленого нашою діє во-історичною «ситуаційністю». Розуміння, разом із тим, є заручником горизонту своєї ситуації, радше, навпаки, горизонт розуміння є змінним і динамічним [11].
Коли йде мова про застосування норм права, наріжним каменем є розуміння взаємозумовленості тексту і контексту. Іншими словами, текст залежить від історичного та культурного контексту, а контекст тексту не вичерпується власне текстуальністю. Очевидно, що контекст лімітує коло можливих інтерпретацій, які можна пристосувати до тексту. Одночасно реконструкція широкого контексту здатна надати тексту його дійсної ваги, ілюмінуючи його історичну, культурну, авторську складові частини.

Зауважимо, що всі існуючі аплікації тексту, тобто його застосування в об'єктивному конкретному історичному контексті, суб'єктивному і інтерсуб'єктивності вимірах (комунікативної ситуації), конституюють єдність досвіду розуміння цього тексту. Це онтологічне коло інтерпретації окреслює корелятивні зв'язки об'єктивної реальності, суб'єкта інтерпретації і його культурне середовище. Отже, на трансформацію змісту ідей впливають ці три фактори в їх корелятивній єдності.

Одночасно будь-яке розуміння тексту неминуче вписано в герменевтичне коло. Автор «Істини і методу» писав про те, що розуміння в людській свідомості структуроване таким чином, що потрапляє на інтуїцію цілого, яка дозволяє повніше розуміти зміст частини і одночасно звертається до розбору частини, щоб досягти цілісності предмета. Таким чином, розуміння цілого і його частин $\epsilon$ циклічним і нескінченним рухом, сутність предмета завжди невіддільна від горизонту буття предмета [10].

Перенесемо напрацювання герменевтичної філософії у площину інтерпретації нормативно-правового акта. По-перше, конкретна норма-правило як дискретна частина повинна інтерпретуватися в ширшому контексті цілого нормативно-правового акта, в нашому випадку - Податкового кодексу України. У цьому сенсі норми-принципи права виступають архітектонікою норм-правил, на яких ті засновані та в радіусі яких повинні інтерпретуватися, або, інакше кажучи, принципи податкового права задають регулятивний горизонт інтерпретації конкретних нормправил у межах тексту Податкового кодексу.

По-друге, така інтерпретація не є усталеною і вичерпною, а зумовлена об'єктивними знаннями про світ, суб'єктивним обрієм інтерпретатора і інтерсуб'єктивною включеністю в певне культурно-комунікативне співтовариство. Спроба нормативного конструювання об'єктивної, єдиної і кінцевої істинності приписів, що нібито досягається завдяки редукуванню партикулярності інтерпретатора та його історичної ситуації, довела 
свою неспроможність, натомість комплексна реконструкція змісту приписів права саме завдяки своїй невіддільності від горизонту, недалекого в даний час в історії і в даній культурі, маніфестує їх динамічну сутність.

Нарешті, проблема юридичної герменевтики базується на тому, що закон виявляється недосконалим не сам по собі, а у зв'язку з недосконалістю людської дійсності в порівнянні з порядком, що таким законом приписується, і тому неможливістю простого застосування норм закону. На думку експонента філософської герменевтики Ганса-Георга Гадамера, помилковим є твердження, що правовий зміст закону цілком однозначний, i сучасна правозастосовна практика виключно слідує його первісному змісту. Натомість юрист, тлумачачи закон із метою конкретного застосування, повинен усвідомлювати зміни правових відносин, які відбулися з моменту прийняття закону, а відповідно, в кожному конкретному випадку заново визначати нормативну функцію закону. Завдання інтерпретації закону постає як слідування правовій думці закону, опосередкування її сучасністю так, щоб конкретний випадок правозастосування отримав справедливе вирішення в правовому сенсі цього закону [11].

Отже, недостатньо розуміння норм податкового законодавства, виходячи з історичних умов, в яких вони приймалися, радше за конститутивним для розуміння цих норм $\epsilon$ конкретизація правої значимості самим процесом тлумачення, а тому і компенсація в кожному практичному випадку строгості закону, виходячи з позиції справедливості. Якщо в тексті відсутній трансцендентний зміст, то інтерпретація здатна виробляти нове правозастосування в залежності від умов, в яких вона постає [12]. Дошукуючись основних метрик правового розуміння в оптиці юридичної герменевтики, ми, таким чином, встановили дієвий характер розуміння як аплікації цілого в тому чи іншому конкретному випадку, в якому відбувається продуктивне розширення норми закону саме як гарантія законності.

Принципи податкового права - це основні ідеї, концепції, які знайшли своє закріплення в правових нормах або тільки сформовані юридично доктриною та які відображають фундаментальні основи податкової політики i забезпечують загальний баланс публічних і приватних інтересів учасників податкових правовідносин. Принципи податкового права - це універсальні ідеї податкового права, що відображають його онтологічну сутність.

У разі нормативного закріплення принципи податкового права можуть формувати принципи податкового законодавства. У той же час до системи принципів податкового законодавства входять спеціальні правила дії податкових актів у часі, просторі і за колом осіб, а також вимоги до їх темпоральної трансформації.

Принципи податкової системи - це засади побудови податкової системи, що регулюють взаємозв'язки елементів цієї системи як сукупності загальнодержавних і місцевих податків та спрямовані на забезпечення ㄲ збалансованості, стабільності і цілісності. Основна мета таких принципів полягає в забезпеченні функціональності статичної системи.

У той самий час принципи оподаткування є основними принципами правового регулювання правовідносин, що складаються в динамічному процесі адміністрування загальнообов'язкових платежів і забезпечують найбільш повну реалізацію фіскального інтересу держави під час обліку економічних можливостей і приватного інтересу платників податків. Їх сутність певною мірою іманентно відображає економічні закони і процеси.

Пункт 4.1 статті 4 Податкового кодексу України передбачає, що податкове законодавство України грунтується на таких принципах, як: загальність оподаткування; рівність усіх платників перед законом, недопущення будь-яких проявів податкової дискримінації; невідворотність настання визначеної законом відповідальності в разі порушення податкового законодавства; презумпція правомірності рішень платника податку; фіскальна достатність; соціальна справедливість; економічність оподаткування; нейтральність оподаткування; стабільність; рівномірність та зручність сплати; єдиний підхід до встановлення податків та зборів.

Наш погляд, принципи, передбачені пунктом 4.1 статті 4 Податкового кодексу України, складаються як із власне принципів податкового законодавства (стабільність оподаткування, презумпція правомірності рішень платника податків та невідворотність настання юридичної відповідальності), так і 3 принципів оподаткування (нейтральність оподаткування, соціальна справедливість, економічність і інші). У той же час стаття 4 ПК України містить ще чотири принципи податкового законодавства, визначені в пунктах 4.2, 4.3, 4.4, 4.5 статті 4 Податкового кодексу України: загальнодержавні, місцеві податки і збори, справляння яких не передбачено цим Кодексом, сплаті не підлягають; податкові періоди і строки сплати податків і зборів встановлюються, виходячи 3 необхідності в забезпеченні своєчасного надходження коштів до бюджетів, з урахуванням 
зручності виконання платником податкового боргу та зменшення витрат на адміністрування податків та зборів; установлення і скасування податків та зборів, а також пільг їх платникам здійснюються відповідно до цього Кодексу Верховною Радою України, а також Верховною Радою Автономної Республіки Крим, сільськими, селищними, міськими радами в межах їх повноважень, визначених Конституцією України та законами України; під час встановлення або розширення наявних податкових пільг такі пільги застосовуються з наступного бюджетного року.

Якщо оцінювати значення принципів закріплених у статті 4 Податкового кодексу України, то, безумовно, вони являють собою аксіологічну основу вказаного нормативноправого акту, його «anima juris». Цінності, що в них закладені, повинні іманентно втілюватись в усіх нормах, що регулюють податкові правовідносини.

Варто зауважити, що принципи оподаткування можуть служити яскравим практичним підтвердженням доречності позиції O.О. Уварової: «Принципи права можна розглядати як інтегруючий елемент природно-правового і позитивістського напрямку правового мислення, свідченням чого є, зокрема, визнання принципів права основою для оцінки санкціонованого державою права на відповідність визнаним у суспільстві цінностям. Вони мають основоположне значення для врегулювання суспільних відносин. Принципи становлять систему вимог, які визначають межі повноважень нормотворчого та правозастосовного органів» [13].

Вони пройшли досить довгий і складний шлях розуміння своєї сутності, внаслідок чого, на думку деяких дослідників, ї зміст залежить від рівня соціального і економічного розвитку суспільства та відображає на відповідному етапі філософії характер взаємодії людини і держави [14]. $\mathrm{y}$ той же час, на наш погляд, сьогодні вони вимагають свого осмислення в рамках саме аксіології юснатуралізму, як їі розуміє професор С.П. Рабинович [15].

Водночас, на наш погляд, позиція, згідно з якою принципи, перераховані у статті 4 ПК України, повинні застосовуватися переважно на стадії встановлення податків, їх основних елементів [16], а також під час внесення змін до окремих елементів податку, є занадто вузьким підходом, який не розкриває закладений у них внутрішній потенціал.

Крім того, ми не схильні розглядати, що «норма-принцип, яка позитивує принцип права й має тільки диспозицію», не володіє «самостійним значенням і слугує лише доповненням іншої норми (нормативної статті), оскільки фактично несе лише допоміжний характер» [17].

Адже в разі розв'язання конкуренції між положеннями статті 4 та інших статей Податкового кодексу України таку конкуренцію не варто сприймати як «Lex specialis» i «Lex generalis», оскільки тут виникає не просто співвідношенням між так званими «відправними нормами» і спеціальними винятковими нормами, а протистояння між вищими ідеалами і конкретним правилом, що описує певне лекало поведінки. Указане правило - окрема вівця, а принцип - це одночасно огорожа, в межах якої пасеться отара, її пастух, який скеровую таку отару, та вівчарка, що охороняє отару від вовків.

У даному контексті слушним вбачається зауваження І.П. Бахновської, що «принципи права можуть бути закріплені в положеннях нормативних актів. Однак формальна визначеність не $є$ їх конститутивною ознакою, оскільки зміст принципу права може бути виведений зі змісту норм, які були сформовані на його основі» [19]. Однак, на думку дослідниці, принцип не може бути закріплений в окремій нормі права, оскільки вона не може повністю охопити і втілити його зміст [20].

Обмеженість прямої дії «принципів» із метою правозастосування критикує O.В. Тимошина. Так, вона вказує, що твердження про те, що принцип, на відміну від правила, не описує конкретну модель поведінки, є тривіальним, оскільки принцип описує абстрактну модель поведінки, і це не якісна відмінність, а відмінність ступеню. Жодна модель поведінки, якою б конкретною вона не була, не перестає бути моделлю, тобто деякою абстракцією. Разом із тим будь-який правовий принцип претендує на визначеність. Доказом є те, що стосовно будь-якого фактичного стану справ можна поставити питання про його відповідність правовому принципу, до того ж, не тільки теоретично, але і практично, наприклад, шляхом звернення з відповідним позовом. Це також є відповіддю на заперечення про те, що принципи не $€$ підставою виникнення прав та обов'язків. Якщо будь-яка особа може звернутися в юрисдикційний орган із вимогою про усунення наслідків порушення деякого принципу шляхом прийняття відповідного рішення, то це означає, що принцип породжує відповідні права та обов'язки [21].

Сприйняття зазначених вище принципів як явищ вищого рівня абстракції в порівнянні 3 нормами права, як певного внутрішнього наративу, тобто норм прескриптивного типу, на наш погляд, дозволить певною мірою подолати конфлікт між орігіналістічніми і неорігіналістічніми підходами до тлумачення [22]. 
Адже, як писав Р.З. Лівшиц, «принципи пронизують процес реалізації права. I під час застосування законів, і під час заповнення прогалин у правовому регулюванні, і в судовій практиці вони слугують векторами правозастосовної діяльності. Принципи права концентрують результат розвитку права, в них втілюється нерозривний зв'язок минулого, сьогодення і майбутнього» [23].

Водночас, попри очевидну, на перший погляд, дуалістичну природу принципів оподаткування як таких, що відображає приватний та публічний інтерес, сутність інтересу, що в них закладена, не перебуває в антагоністичному протистоянні «держава проти платника податків», а існує у внутрішній єдності. Адже всі вони спрямовані на захист інтересів особи: як «я - егоїстична приватна особа» і як «я - як частина соціуму».

Саме тому з метою тлумачення та правозастосування ї можна розглядати лише в системній єдності, оскільки жоден із них не має заздалегідь визначеної переваги над іншим, Як наслідок, у цілому вони створюють певну систему стримування та противаг. Зокрема, дискурс про необхідність упровадження певних податкових пільг не може залишитись без оцінки на предмет збереження чи порушення такими нововведеннями балансу між принципами рівності в оподаткуванні з принципом справедливості оподаткування та принципом нейтральності оподаткування.

Варто зауважити, що критика В. Гончарова підходів до тлумачення, що склалися у вітчизняній правовій системі [24], є неймовірно слушною саме в контексті недоціненості значення принципів оподаткування, закріплених у статті 4 Податкового кодексу України, в цілях правозастосування податкових норм.

При цьому систему принципів, що сформована в Податковому кодексі України, не можна вважати остаточно завершеною та сталою конструкцією, оскільки вони є іманентним відображенням постійної динаміки ідеологій доктрини податного права. Адже від того, якій ідеології оподаткування надається перевага (етатиській [25], людиноцентриській чи егалітарній), залежить, чому надається перевага в застосуванні одних принципів при ігноруванні інших.

Водночас використання принципів, вказаних у статті 4 Податкового кодексу України, саме в сукупності та нерозривній єдності дозволить побудувати податкову систему України на основі паритету та балансу інтересів держави та індивідуума, що цілком відповідатиме ідеології концепції егалітаризму. Відповідно до егалітаризму податкове право за своєю при- родою і для індивіда-платника податків, і для держави однаковою мірою повинне породжувати права і обов'язки. Із позицій егалітарної концепції завдяки принципу симетрії сутність податкового права полягає в нормуванні й органічному сполученні двох невід'ємних сторін, атрибутів єдиного начала - природних потреб індивіда, їх індивідуальної для кожного й загальної для всіх частин [25].

\section{Висновки}

Таким чином, можна констатувати, що інтерпретатор постійно знаходиться у процесі пізнання принципів податкового права, 1 цей процес безпосередньо залежить від горизонту пізнання самого інтерпретатора. Чим більше дізнається інтерпретатор, тим ширше він розуміє ті чи інші принципи податкового права. У зв'язку із цим немає чітких критеріїв, які сприяють пізнанню суті принципів, оскільки ми постійно перебуваємо в процесі пізнання. Таким чином, суть принципів податкового права тією чи іншою мірою залежить від суб'єктивного горизонту пізнання інтерпретатора, інтерсуб'єктивності включеності в суспільні відносини, а також від об'єктивних знань про світ.

\section{Список використаних джерел:}

1. Лившиц Р.3. Теория права : учебник. Москва : БЕК, 1994. С. 197.

2. Алексеев С.С. Восхождение к праву. Поиски и решения. Москва : Издательство НОРМА, 2001. C. 607

3. Алексеев С.С. Восхождение к праву. Поиски и решения. Москва : Издательство НОРМА, 2001. C. 607.

4. Карташов В.Н. Принципы права: понятие, структуры, функции. Юрид. зап. Ярослав. гос. ун-та им. П.Г. Демидова. Ярославль : ЯрГУ, 2006. Вып. 10. С. 4

5. Карташов В.Н.Принципы права: понятие, структуры, функции. Юрид. зап. Ярослав. гос. ун-та им. П.Г. Демидова. Ярославль : ЯрГУ, 2006. Вып. 10. С. 4

6. Демин А.В. Неопределенность в налоговом праве и правовые средства ее преодоления : диссертация на соискание ученой степени доктора юридических наук. Екатеринбург. 2014. С. 15.

7. Гаджиев Г.А. Онтология права: (критическое исследование юридического концепта действительности) : монография. Москва : Норма: ИНФРАМ, 2013. С. 33.

8. Malpas Jeff. "Hans-Georg Gadamer". The Stanford Encyclopedia of Philosophy (Winter 2016 Edition). Edward N. Zalta (ed.). URL $<$ https://plato.stanford.edu/archives/win2016/ entries/gadamer $/>$.

9. Rescher Nicholas, 1997, Objectivity. The Obligations of Impersonal Reason, Notre Dame, IN and London : University of Notre Dame Press. P. 201 
10.Богачов А.Л. Герменевтичний підхід у філософії. Філософська думка. 2013. № 5. С. 45.

11. Гадамер X.-Г. Истина и метод: Основы филос. Герменевтики / Общ. ред. и вступ. ст. Б.Н. Бессонова. Москва: Прогресс, 1988. С. 196-206.

12. Tanzil Chowdhury. Hans-Georg Gadamer: Hermeneutics. Critical Legal Thinking. Law and the Politics. 2016. URL : http://criticallegalthinking. com/2016/06/17/hans-georg-gadamerhermeneutics/.

13. Уварова О.О. Загальні принципи права та їх роль у правозастосуванні з позицій природно-правового і позитивістського підходів до права. Вісник Академії правових наук України. 2008. № 2. C. 250 .

14. Афанасьев М.П., Афанасьев Я.М. Методологические и теоретические основы формулировки закона А. Вагнера. Подходы к его тестированию. Вопросы государственного и мунииипального управления. № 3. 2009. С. 58-59.

15. Рабінович С.П. Природно-правові підходи в юридичному регулюванні : монографія. Львів : Львівський державний університет внутрішніх справ, 2010. С. 95.

16. Ясько І.В. Принципи оподаткування. Вісник Національного університету «Львівська політехніка». Юридичні науки. 2015. № 824. С. 136.

17. Скурно Е.В. Правовые принципы и принципы права: их выражение в правовой системе, системе права и законодательстве РФ (актуальные проблемы теории и практики). Новая правовая мысль. 2005. № 6. С. 23.

18. Рішення Конституційного Суду України у справі за конституційними поданнями Мініс- терства внутрішніх справ України і Міністерства фінансів України щодо офіційного тлумачення положень частини шостої статті 22 Закону України «Про міліцію» та частини. Офімійний вісник Украйни. 1999. № 27. С. 177.

19.Лившиц Р.3. Теория права : учебник. Москва : БЕК, 1994. С. 197.

20. Бахновська І.П. Питання співвідношення принципів і норм права та їх місця у механізмі правового регулювання. Університетські наукові записки. 2013. № 1 (45). С. 45.

21. Тимошина Е.В. Нормы-правила и нормыпринципы: последствия нормативного дуализма для методологии судебного толкования. Современные подходы к пониманию права и их влияние на развитие отраслевой юридической науки, законодательства и правоприменительной практики: сб. науч. тр. / учреждение образования «Акад. М-ва внутр. дел Респ. Беларусь» ; под общ. ред. В.И. Павлова, А.Л. Савенка. Минск : Академия МВД, 2017. С. 257-258.

22. Гончаров В. Від старої теорії тлумачення до нової: основні виклики та рішення. Філософія права і загальна теорія права. № 1-2/2014. 53 с.

23. Лившиц Р.3. Теория права : учебник. Москва : БЕК, 1994. С. 200.

24. Лившиц Р.3. Теория права : учебник. Москва : БЕК, 1994. С. 200.

25. Гаврилюк Р.О. Загальнонауковий методологічний принцип відповідності та наука податкового права. Науковий вісник Чернівеиького університету : збірник наукових пращь. Вип. 533 : Правознавство. Чернівці : «Рута», 2010. C. 71-77.

В статье рассматривается вопрос толкования для правоприменительной деятельности приниипов налогообложения. В частности, автором отмечается, что толкование конкретной нормьприниипа должно осуществляться не обособленно, а в контексте целого нормативно-правового акта, то есть Налогового кодекса Украины. Кроме того, интерпретаиия не является исчерпьвающей, а обусловлена объективными знаниями о мире, субъективным горизонтом интерпретатора и интерсубъективной включенностью в определенное культурно-коммуникативное сообщество. Автор отмечает, что ошибочной является практика, когда интерпретатор пытается исследовать первоначальный смысл закона, вместо этого нужно осознать изменения, которые произошли с момента принятия закона, и в каждом конкретном случае определять нормативную функцию закона, иными словами - нужно понять сущность закона с учетом конкретных объективных обстоятельств.

Ключевые слова: толкование закона, принципы налогового права, юридическая герменевтика, горизонт познания интепретатора.

The article describes the issue of interpretation of taxation principles for law enforcement. In particular, the author notes that the interpretation of a particular norm-principle should be carried out not separately, but in the context of a whole regulatory legal act, that is, the Tax Code of Ukraine. In addition, the interpretation is not comprehensive, but it caused by objective knowledge of the world, the subjective horizon of the interpreter and intersubjective inclusion in a certain cultural and communicative community. The author notes that it is erroneous practice when the interpreter tries to investigate the original meaning of the law, instead it's necessary to realize the changes that have taken place since the adoption of the law, and in each case to determine the normative function of the law, in other words - it's necessary to understand the essence of the law with regard to specific circumstances.

Key words: interpretation of the law, principles of tax law, legal hermeneutics, horizon of knowledge of the interpreter. 